\title{
The current state of mountain meadow soils of subalpine pasture ecosystems of the Central Caucasus (elbrus altitudinal zonality)
}

\author{
Olga Gorobtsova, Viktoria Chadaeva, Fatima Gedgafova, Tatyana Uligova, Rustam Tembotov*, and Elena \\ Khakunova
}

Tembotov Institute of Ecology of Mountain Territories of Russian Academy of Science, 360051 Nalchik, Russia

\begin{abstract}
Intensive recreational, agricultural and logistics land use in uplands leads to their transformation and degradation. Subalpine meadow ecosystems of Central Caucasus are traditionally used for grazing and mowing. The work determined the current state of soils on pastures (mountain meadow-steppe subalpine soil and mountain meadow subalpine soil) and the level of changes of their properties under different stages of pasture degradation were defined. The efficacy of 4-stage assessment system for evaluating the pasture degradation of grasslands dominated by Bromus variegatus M. Bieb. was shown for the assessment of soil cover condition. The reduce of estimated soil indicators and degradation of soils under pastures with maximal degradation stage (DS3) of meadow ecosystems was statistically significant.
\end{abstract}

\section{Introduction}

Intensive recreational, agricultural and logistics land use in uplands leads to their transformation and degradation. Subalpine meadow ecosystems of Central Caucasus (from $1500-1600$ to $2400-2800 \mathrm{~m}$ above sea level) are traditionally used for grazing and mowing. Long term grazing activities deeply influence on vegetation and soil covers. Due to the huge scale of this influence, some researchers admit that all upland meadow ecosystems of Central Caucasus are semi-natural highly productive pasture ecosystems that were formed in the conditions of long-term grazing [1]. In the last 100 years the character of land use on upland pastures of Central Caucasus was changing; the grazing intensity varied according to economic situation. Research of upland meadow pastures in 1950-1980 shown that significant degradation changes of soil and plant cover happened due to unrestrained grazing [2]. Widespread land tenancy is common in Kabardino-Balkaria [3], what leads to inconsistent exploitation of pastures based on distantpasture type of livestock farming and intensive grazing [4]. Collection and systemization of detailed information for monitoring and assessment of the state of meadow ecosystems is relevant in existing conditions for conservation of natural resources of Central Caucasus uplands.

The most common soil types under meadow ecosystems are mountain meadow-steppe subalpine and mountain-meadow subalpine soils [5]. Pasture degradation of soil cover appears as root mat disruption, formation of trodden paths, appearance of erosion process that lead to a partial or full loss of topsoil humic horizons in upland soils. Soils under pastures undergo a change in next properties: morphological (thickness of soil profile, presence and thickness of root mat horizon), physical and chemical (moisture, density, humic content), biological (enzyme activity, soil microbial biomass). The control and assessment of soil changes degree allow to track the dynamic of degradation processes in pasture meadow ecosystems of Central Caucasus.

In this research we aimed to assess the current state of upland soils of subalpine meadow ecosystems in Central Caucasus under different stages of pasture degradation. The assessment was based on stable (physical and chemical) and dynamic (biological) soil properties.

\section{Objects and methods}

The study was conducted in the area of Chegem, elbrus altitudinal zonality, upstream of rivers Bashil and Gara-Auzusu, within closure 43.183359-43236993 N., 42.976616-43.134518 E., at the altitude from 1691 to 2110 above sea level (Figure 1.) [6]. The climate of the area is highland, cold and humid. The average temperature is $+12.6{ }^{\circ} \mathrm{C}$ in July and $-6.7{ }^{\circ} \mathrm{C}$ in December, annual precipitation is about $900 \mathrm{~mm}$ on the

* Corresponding author:tembotov.rustam@mail.ru 
altitude of $2150 \mathrm{~m}$ above sea level. Significant variation in hydrothermal regime of slopes with different exposure defines the specificity of soil-forming processes and leads to the formation of complex soil cover [7-9]. There are several types of natural plant cover: steppificated meadows dominated by fescue, by Cyperaceae (lowsedge) and Festuca sp., and steppes dominated by
Festuca sp., by forbs, fescue and feather grass. Untransformed grasslands dominated by Bromus variegatus $\mathrm{M}$. Bieb. were preserved only on the plots at a far distance form sheepfolds, cattle tracks and watering holes, in the boundaries of designated conservation areas.

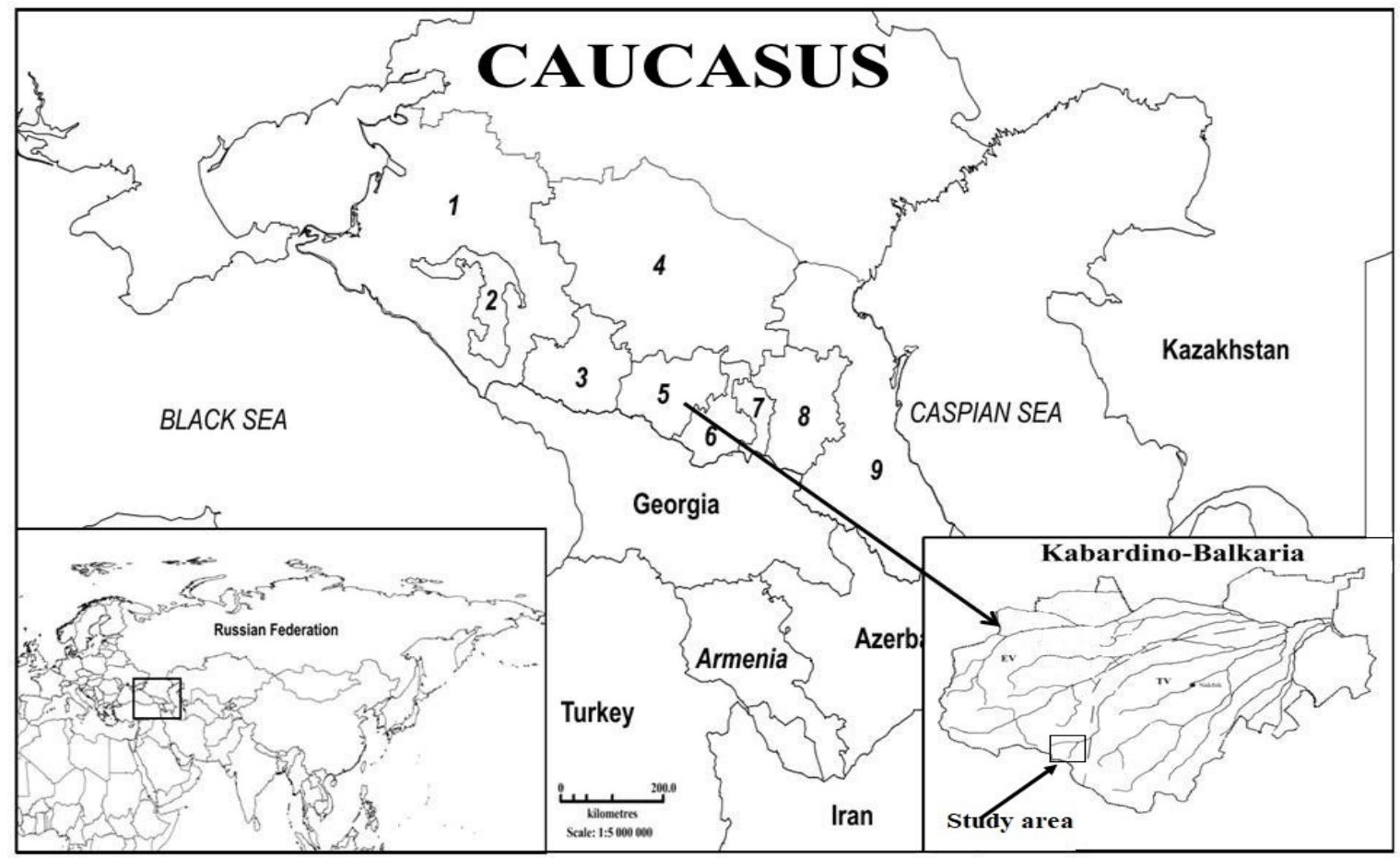

Fig. 1. Location and schematic map of the research area

Two types of soil were studied: mountain steppemeadow and mountain-meadow subalpine soils (according to the Classification and Diagnostics of Soils of the Soviet Union, 1977) [10]. In the Classification and diagnostic of Russian soils (2004) these soils are referred to the dark humic type in the division of organoaccumulative soils. In World Reference Base for Soil Resources 2014 these soils are attributed to Umbrisols group [11].

Field survey was conducted in July 2020 using standard soil and geobotanics methods [12-18]. 12 model plots were established on the representative sites on foothills, on low pitched fans, and on fluvial terraces above the flood plains. The square of model plots was $900 \mathrm{~m}^{2}$. Locations for model plots were picked with consideration to minimize the influence of natural factors (slope exposure and processes, presence of cliff debris, rock outcrops, etc.) and to outline and assess the influence of different levels of pasture degradation on soil and plant cover.

Model plots (MP) were placed on forb-cereal meadows with dominance of Bromus variegatus. This vegetation type is the most spread in subalpine belt and characterized by average length of stand $25-30 \mathrm{~cm}$ and significant layering. Typical motley grasses species there were Betonica macrantha K. Koch, Veronica gentianoides Vahl, Geranium sylvaticum L., Persicaria bistorta (L.) Samp., Galium verum L., Phleum phleoides (L.) H. Karst., Carex humilis Leyss etc. Total vegetation coverage, average grass height $(\mathrm{cm})$, coverage of species (\%), species richness (on $900 \mathrm{~m}^{2}$ ) was estimated for each MP during field surveys. One of four degradation stages (DS0, DS1, DS2, DS3) was specified for each MP based on the plant community dominants, synanthropic species occurrence, the character of grass stand layering, the presence of eroded and uncovered soil sites, the density and width of root mat, the remoteness from mowed places and cattle trails, the accessibility for grazing. The gradation of meadow degradation stages (Table 1.) is based on previous research and is tested in this study for to assess changes in the state of the soil cover at different levels of stocking rates $[19,20]$. No untransformed grasslands (DS0) were found in the study area, as there were signs of grazing or mowing throughout the whole area.

Morphological and genetic properties of soils were studied using the full soil profile description for each MP. Mixed samples for characterization of physical, chemical and biological topsoil properties $(0-10 \mathrm{~cm})$ were taken using envelope method. Soil map [21] was used to choose the place for sampling. The soil classification was performed according to the 
Classification and Diagnostics of Soils of the Soviet Union, 1977 [10].

Table 1. Stages of pasture degradation of studied meadows and the number of model plots in the area of mountain meadowsteppe and mountain-meadow subalpine soils of the studied territories

\begin{tabular}{|c|c|c|}
\hline \multicolumn{2}{|r|}{ Pasture degradation stages } & $\begin{array}{c}\text { Number } \\
\text { of model }\end{array}$ \\
\hline DS0 & $\begin{array}{l}\text { Zero degradation stage: untransformed } \\
\text { grasslands dominated by Bromus } \\
\text { variegatus (vegetation coverage not less } \\
\text { than } 30-35 \% \text { ) with no signs of grazing }\end{array}$ & 1 \\
\hline $\begin{array}{l}\text { DS1 } \\
\text { Fig. } 2 .\end{array}$ & $\begin{array}{l}\text { First stage of pasture degradation: } \\
\text { visually undisturbed meadows with } \\
\text { noticeable layering and weak } \\
\text { infestation with synanthropic species }\end{array}$ & 4 \\
\hline $\begin{array}{l}\text { DS2 } \\
\text { Fig. } 3 .\end{array}$ & $\begin{array}{l}\text { Second stage of degradation: meadows } \\
\text { with vegetation coverage of Bromus } \\
\text { variegatus not more than 5-10\% and } \\
\text { high abundance of Trifolium (clover) } \\
\text { and Alchemilla species that are resistant } \\
\text { to grazing. These meadows are } \\
\text { characterized by two-layer structure and } \\
\text { well-developed root mat without } \\
\text { uncovered soil. }\end{array}$ & 4 \\
\hline $\begin{array}{l}\text { DS3 } \\
\text { Fig. } 4 .\end{array}$ & $\begin{array}{l}\text { Third stage of degradation: low-grass } \\
\text { (with grass height } 2-3 \mathrm{~cm} \text { high) } \\
\text { meadows dominated by species of } \\
\text { Alchemilla, fescue, clovers, and } \\
\text { plantains. In addition, these meadows } \\
\text { are characterized by poorly developed } \\
\text { root mat, the presence of eroded and } \\
\text { micro-terraced areas, and patches of } \\
\text { bare soil. }\end{array}$ & 4 \\
\hline
\end{tabular}

Laboratory analytical studies were performed threeto nine fold. Humus content was estimated using Tyurin's method with modification by Nikitin [22]. Soil $\mathrm{pH}$ of salt extract $(\mathrm{KCl} \quad 0.1 \mathrm{n})$ was estimated potentiometrically. Soil density $\left(\mathrm{gr} / \mathrm{cm}^{3}\right)$ was estimated according to All Union State standard 5180-2015 [23]. Activities of urease, phosphatase, invertase, dehydrogenase were estimated colorimetrically; catalase activity was estimated gasometrically according to Galstyan's methods as modified by Khaziev [24]. The physiological activity of the microbial biomass was determined by the rate of basal and substrate-induced respiration (BR and SIR) [25]. The determination was carried out in accordance with the methodological developments of Ananyeva [26]. To calculate the carbon content of microbial biomass (Cmic), the SIR rate was expressed in $\mu \mathrm{lCO} 2 / \mathrm{g}$ soil per hour. Cmic $(\mu \mathrm{g} \mathrm{C} / \mathrm{g}$ soil $)=\operatorname{SID}(\mu \mathrm{l} \mathrm{CO} 2 / \mathrm{g}$ soil $/$ hour $) \times 40.04+0.37$ [27] .

Statistical processing of the data obtained was carried out using the Statistica-10.0 program. The significance of differences in the studied soil characteristics was assessed using the Student's t-test. The study adopted a significance level of 0.05 .

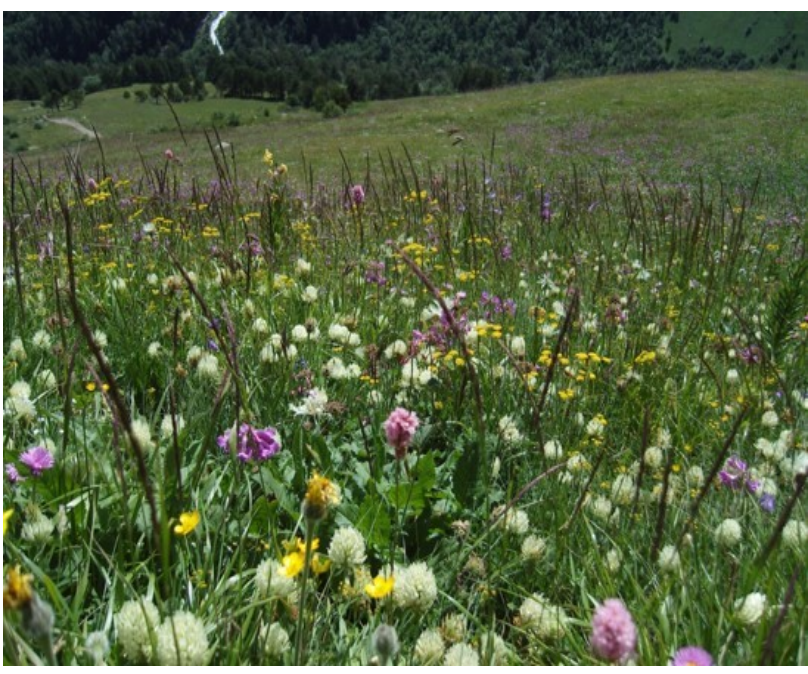

Fig. 2. First grassland degradation stages (DS1)

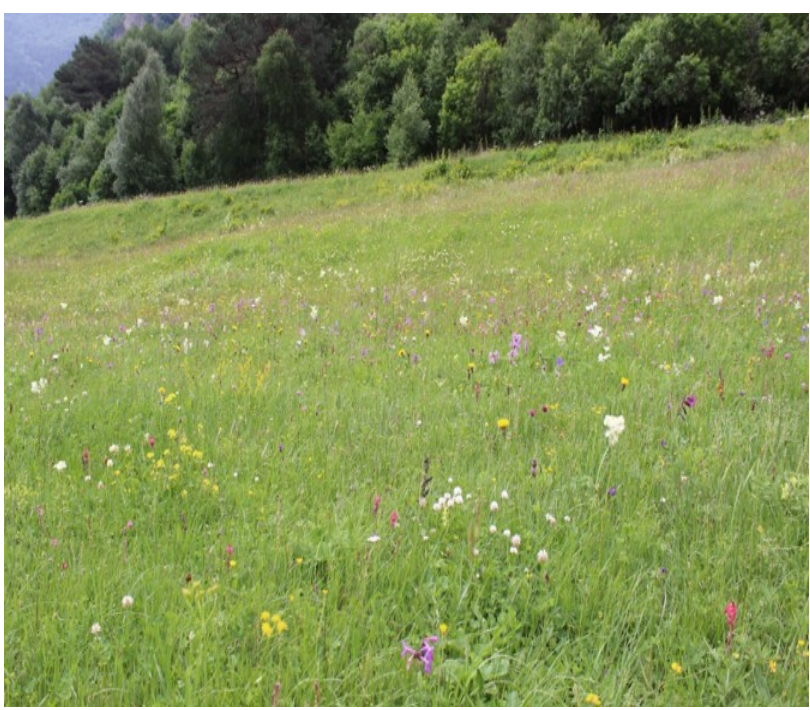

Fig. 3. Second grassland degradation stages (DS2)

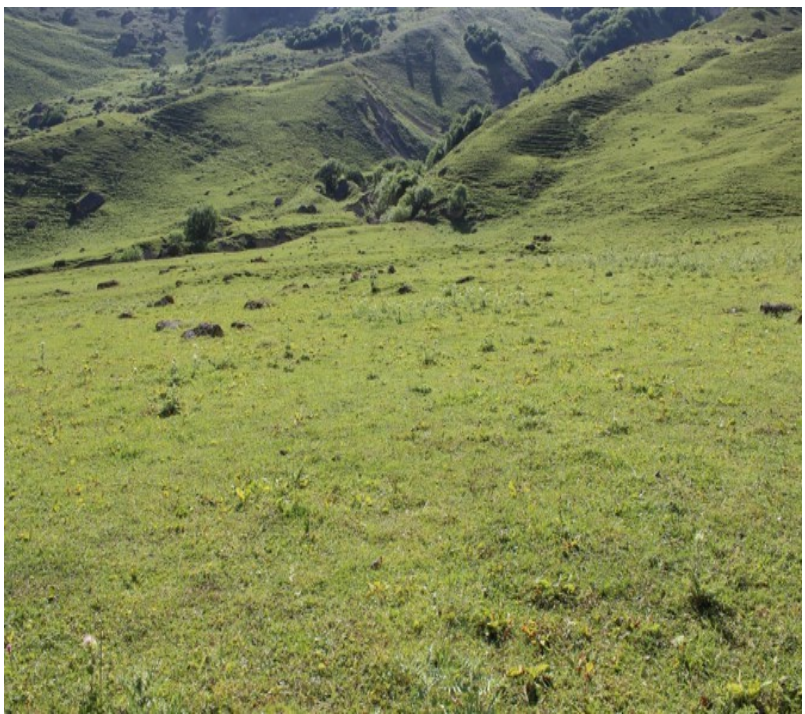

Fig. 4. Third grassland degradation stages (DS3) 


\section{Results and Discussion}

Model plots are located on pasture areas with two types of soil that have similar genesis, but different specific characteristics of soil formation conditions [10]. Mountain meadow-steppe subalpine soils are distributed in the lower part of the subalpine belt, mainly on the southern slopes, in moderately humid conditions: periodically flushed soil water regime, moisture coefficient 1-2. These soils are formed under steppe meadows, meadow steppes and in some xeromorphic areas within the range of mountain meadow subalpine soils. The parent rock for these soils is non-carbonaceous eluvio-diluvium of bedrocks. The soil profile (Ad-A-BBC-C) with a depth from $20-25 \mathrm{~cm}$ to $40-50 \mathrm{~cm}$ is poorly differentiated. Mountain meadow-steppe subalpine soils mostly have loose root mat, low and medium profile depth, weak and medium stone content. The granulometric composition varies from heavy loam to sandy loam, but most common is medium loam. Mountain meadow subalpine soils occupy the tops of ridges, slopes of all exposures and various steepnesses. Parent rocks are mainly eluvio-diluvium of noncarbonaceous bedrocks, or loose sedimentary rocks in some cases. A thick snow cover results in weak freezing of mountain meadow soils, and an excess of moisture throughout the year forms a leaching water regime (moisture coefficient 2-3). The soil profile (Ad-A-B-BCC) sometimes could be $40-50 \mathrm{~cm}$ in depth, but more often is 20-40 cm (medium-thick soils). With a high anthropogenic load, a well-defined and dense root mat horizon $(12-15 \mathrm{~cm})$ appears. The soil profile is poorly differentiated, the transitions between the horizons are gradual, noticeable by color, structure, abundance of stony inclusions and the degree of development of the root system of herbaceous plants. Soils with loose root mat, low and medium profile depth, with low and medium stone content are widespread in the study area; medium loamy granulometric composition prevails.

Comparison of the data characterizing the upper horizons $(0-10 \mathrm{~cm})$ shown that bulk density indices are significantly different between the considered soil types. Hydrothermal conditions and the character of the vegetation cover determine higher bulk density of mountain meadow-steppe soils compared to mountain meadow soils (average values $1.1 \pm 0.08 \mathrm{~g} / \mathrm{cm}^{3}$ and $0.7 \pm 0.05 \mathrm{~g} / \mathrm{cm}^{3}$, respectively; $\mathrm{t}=2.8 ; \mathrm{p}=0.02$ ). Mountain meadow soils that are formed in more humid and cold conditions contain less decomposed plant residues, which reduce the bulk density and gives some "fluffiness" to their upper horizons. The differences in the soil suspension $\mathrm{pH}(\mathrm{KCl} 0.1 \mathrm{n})$ are close to significant $(\mathrm{t}=2.0 ; \mathrm{p}=0.07)$. The average $\mathrm{pH}(\mathrm{KCl} 0.1 \mathrm{n}$.) of mountain meadow soil $(4.96 \pm 0.2)$ is noticeably lower than that of mountain meadow-steppe soil $(5.59 \pm 0.2)$. The results obtained correspond to the peculiarities of the genesis of the considered types, and a higher level of acidity is one of the classification features of mountain meadow soils [20].

No significant differences were found between the other measured parameters for the upper horizons of two soils, which make it possible to combine the data characterizing the considered soil types into general samples. Close values of the soils upper horizons parameters could possible reflect the processes of steppe formation in subalpine meadows. Presumably, one of the reasons of steppe formation is anthropogenic aridization, which causes compaction, soil drying, and excessive overheating of bare areas. According to the data on the grazed areas of the subalpine meadows of the Central Caucasus, the soil temperature, even at a depth of $50 \mathrm{~cm}$, is on average $3{ }^{\circ} \mathrm{C}$ higher and the moisture content is 5$9 \%$ lower than in undisturbed ecosystems. The upper horizons of pasture soils are exposed to a much more severe impact, as evidenced by the information presented below.

Soils of pastures are thoroughly characterized by the data obtained as a result of the study (Table 2.). Soils of the MP belong to the types of loose soddy (20-50\% of roots from the volume of the root mat, or soddy horizon), thin (thickness of $\mathrm{A}+\mathrm{B}$ horizons is less than $20 \mathrm{~cm}$ ) and medium-thick (A + B 20-40 cm). The percentage of crushed stone from the volume of the horizons varied and was less than $10 \%$ (rubbly), $10-20 \%$ and $20-40 \%$ (low and moderately stony soil). The loose composition of the upper horizons $\left(<1.1 \mathrm{~g} / \mathrm{cm}^{3}\right)$ in the soils of the main part of the MP is due to the developed root system of herbaceous plants, the activity of the soil mesofauna and a high content of weakly decomposed organic residues. The relatively low values of the density of soils damaged by active grazing are associated with a high content of organic residues of varying degrees of decomposition and granulometric composition for the subalpine belt [8].

The most alarming signs of pasture degradation are the reduction of thickness of whole soil profile and of root mat horizon (Table 2.). The total plant biomass that gets into soil is reduced due to active grazing, while root mat that protects soil from erosion is weakened or destroyed by overbrowsing and animal trampling. Notably, average values of soil profile thickness for weakly and moderately grazed meadows (DS1 and DS2) are not significantly different. A significant reduce of these indicators is observed in comparison for data for model plots with DS2 and DS3 $(\mathrm{t}>3.4 ; \mathrm{p}<0,01)$. Consequently, the decrease of soil profile thickness can serve as indicators of soil degradation and severe disturbance of meadow biogeocenoses.

An acidic reaction $(\mathrm{pH}(\mathrm{KCl} 0.1 \mathrm{n})<6.0$.$) is common$ for mountain meadow and mountain meadow-steppe soils; the acidity of which is due to the high content of $\mathrm{H}^{+}$and $\mathrm{Al}^{3+}$ in the soil absorbing complex and low saturation of the bases (from $6-10 \%$ to $60-70 \%$ ) [10]. The data obtained suggests that in soils of MPs under intense grazing (DS3) the process of acidity reduction is possible. This assumption is confirmed by comparing the data characterizing the MPs of the second and third stages of the degradation (DS2 and DS3). The soils of the most damaged meadows (DS3) are characterized by a significant change in the level of acidity to more neutral values $(\mathrm{t}=5.9 ; \mathrm{p}=0.001)$. 
Table 2. Average indicators characterizing the physical, chemical and biological properties of the upper horizons $(0-10 \mathrm{~cm})$ of the soils of the model plots located in meadows at various stages of pasture degradation.

\begin{tabular}{|c|c|c|c|}
\hline \multirow[t]{2}{*}{ Indicators } & \multicolumn{3}{|c|}{$\begin{array}{c}\text { Average values of indicators } \\
\text { of soils on MP with different stages } \\
\text { of degradation }\end{array}$} \\
\hline & DS1 & DS2 & DS3 \\
\hline $\begin{array}{l}\text { Soil profile } \\
\text { thickness, } \mathrm{cm}\end{array}$ & $40.6 \pm 4.4$ & $38.1 \pm 5.6$ & $17.8 \pm 1.7$ \\
\hline $\begin{array}{l}\text { Root mat horizon } \\
\text { thickness, cm }\end{array}$ & $13.0 \pm 0.7$ & $12.9 \pm 0.6$ & $4.5 \pm 0.5$ \\
\hline $\begin{array}{l}\text { Moisture measured } \\
\text { on-site, \% wt }\end{array}$ & $52 \pm 11$ & $41 \pm 14.9$ & $34.2 \pm 4.6$ \\
\hline Soil density, $\mathrm{g} / \mathrm{cm}^{3}$ & $0.7 \pm 0.07$ & $0.9 \pm 0.1$ & $1.1 \pm 0.1$ \\
\hline $\mathrm{pH}(\mathrm{KCl} \quad 0,1 \mathrm{n})$. & $4.8 \pm 0.1$ & $5.3 \pm 0.2$ & $6.0 \pm 0.1$ \\
\hline Humic content, $\%$ & $16.4 \pm 2.9$ & $10.4 \pm 1.5$ & $7.5 \pm 1.0$ \\
\hline Humus stock, t/ha & $141 \pm 23$ & $95 \pm 17$ & $79 \pm 6$ \\
\hline $\begin{array}{l}\text { Basal respiration } \\
\text { (BR), } \mu \mathrm{g} \mathrm{CO} 2-\mathrm{C} / \mathrm{g} \\
\text { of soil/hour }\end{array}$ & $21.7 \pm 5.3$ & $15.9 \pm 1.7$ & $10.9 \pm 0.9$ \\
\hline $\begin{array}{l}\text { Substrate induced } \\
\text { respiration (SIR), } \mu \mathrm{g} \\
\mathrm{CO}_{2}-\mathrm{C} / \mathrm{g} \text { of } \\
\text { soil/hour }\end{array}$ & $97.1 \pm 19.3$ & $70.6 \pm 6.2$ & $41.3 \pm 6.3$ \\
\hline Cmic, $\mu \mathrm{g}$ C/g soil & $3887 \pm 771$ & $2826 \pm 248$ & $\begin{array}{c}1652 \pm 25 \\
0 \\
\end{array}$ \\
\hline Cmic/Corg, \% & $4.0 \pm 0.2$ & $5.0 \pm 0.8$ & $4.5 \pm 0.4$ \\
\hline $\begin{array}{l}\text { Catalase activity, } \mathrm{ml} \\
\mathrm{O}_{2} / 1 \mathrm{~g} / 1 \mathrm{~min}\end{array}$ & $3.3 \pm 0.7$ & $2.9 \pm 0.8$ & $2.4 \pm 0.5$ \\
\hline $\begin{array}{l}\text { Dehydrogenase } \\
\text { activity, mg TPP, } \\
10 \mathrm{~g} / \text { day }\end{array}$ & $1.3 \pm 0.2$ & $1.4 \pm 0.3$ & $1.1 \pm 0.4$ \\
\hline $\begin{array}{l}\text { Invertase activity, } \\
\text { mg of glucose/ } \\
\text { 1g/day }\end{array}$ & $58.4 \pm 13.7$ & $44.9 \pm 10.6$ & $31.2 \pm 5.6$ \\
\hline $\begin{array}{l}\text { Urease activity, mg } \\
\mathrm{NH}_{3}, 10 \mathrm{~g} \text { /day }\end{array}$ & $30.3 \pm 13.1$ & $14.8 \pm 2.4$ & $20.9 \pm 7.5$ \\
\hline $\begin{array}{l}\text { Phosphatase } \\
\text { activity, mg } \\
\mathrm{P}_{2} \mathrm{O}_{5} 100 \mathrm{~g} / \text { hour }\end{array}$ & $\begin{array}{c}189.5 \pm 56 \\
9\end{array}$ & $83.0 \pm 25.5$ & $46.6 \pm 8.5$ \\
\hline
\end{tabular}

The accumulation of humate-fulvic humus, or humus of type "moder" occurs in conditions of the acidic reaction in the upper organo-accumulative soil horizons of the subalpine belt soil. Most soils of MPs contain more than $7 \%$ of organic matter. The accumulation of organic matter in the soils of the subalpine belt is promoted by the climatic conditions of the uplands, the herbal vegetation of subalpine meadows and the high activity of the soil mesofauna [28]. Pasture land use leads to the humus loss of the soils under study. The reduction in the humic content and humus stock in the upper horizons $(0-10 \mathrm{~cm})$ on the meadows with an increase in the degradation stage is respectively $38 \%$ and $37 \%$ (when comparing average values for DS1 and DS2) and $28 \%$ and $17 \%$ (when comparing DS2 and DS3). If compare the least (DS1) and most (DS3) damaged meadows, the loss of organic matter in the upper horizons is statistically significant $(\mathrm{t}=1.6 ; \mathrm{p}=0.1)$ and amount to $54 \%$ (humic content) and $44 \%$ (humus stock).

Organic residues and their decomposition products are a substrate for soil microbiota; therefore, a close correlation was established between the microbial and humic indicators $(r=0.7-0.9)$. The soils of most MPs are rich in organic carbon and have high microbial activity.

The basal respiration (BR) characterizes the background respiratory activity of the microbial biomass, which decreases from high to medium values, as the degradation processes intensify (up to $50 \%$ decrease in DS3 compared to DS1). A similar trend is observed when comparing the substrate-induced respiration (SIR) data, which allows judging the physiological potential of the soil microbiota. SIR consistently decreased with the degradation stage; however, even the most damaged soils (DS3) have high values of this indicator, which shows that the potential of the microbial pool is preserved in them.

Cmic content is an informative quantitative indicator that allows assessing the microbial abundance in the studied soils. Soils of all MPs are characterized by [29] a very high content of $\mathrm{Cmic}(>1500 \mu \mathrm{g}$ of $\mathrm{C} / \mathrm{g}$ of soil). Consequently, despite the negative changes that occurred in the most damaged areas (DS3) and the decrease in Cmic (by $58 \%$ compared to DS1), microbial biocenoses in soils under intense grazing are actively functioning, and the soil with a decrease in the pasture load should be capable for self-restoration. This is confirmed by the values of $\mathrm{Cmic} / \mathrm{Corg}$, which indicate the proportion of microbial biomass carbon in the total organic carbon of the soil and is usually $2-5 \%$. The values of this ecophysiological parameter indicate that the soils of all MPs have a sufficient microbial biomass, which is able to recycle the abundant organic residues of the herbal vegetation of subalpine meadows and mountain steppes. Thus, the analysis of microbial and ecophysiological properties of MPs soils indicates the presence of abundant and active microbial biomass in the soils of the subalpine belt. Despite a relatively high degree of degradation change in the considered parameters in the soils of heavily grazed pastures (DS3), we cannot assume that microbial communities have lost the important functions and the ability to self-restoration.

Enzyme activity is an indicator of the intensity and direction of soil biochemical processes. We have considered the activity of enzymes belonging to two classes: redox enzymes (catalase and dehydrogenase) and hydrolytic enzymes (invertase, urease and phosphatase). Analysis of the data obtained suggests that the intensity of oxidation-reduction processes in the soils of all MPs is low: catalase activity is low, dehydrogenase activity is very weak. It is possible that acidic conditions in the considered soil types inhibit the activity of these enzymes. Degradation stage doesn't influence the intensity of redox processes [30]. Depending on degradation stages, the activity of catalase decreases slightly, dehydrogenase activity fluctuates within close values $(\mathrm{t}<1.1 ; \mathrm{p}>0.3)$.

The activities of hydrolytic enzymes are higher compared to redox enzymes and generally decrease with 
an increase in the degradation stage. The most noticeable decrease was observed for the phosphatase activity (from very high (DS1) to medium (DS3), $\mathrm{t}=2.5 ; \mathrm{p}=0.04)$. Invertase activity changes from high (DS1) to medium (DS3) $(\mathrm{t}=1.8 ; \mathrm{p}=0.1)$. The urease activity in the soils of the most degraded meadows (DS3) slightly increases in comparison with less degraded ones (DS2), but remains within the medium values. This may be explained by the manure presence, which is abundant on heavily grazed pastures.

The obtained data indicate that the oxidationreduction processes in the studied soils are less intense than the hydrolytic ones. Hydrolytic enzymes actively catalyze the destruction reactions of organic compounds with high molecular weight, including animal manure. These compounds enrich soils with important nutrients that are available for plants (nitrogen, phosphorus) and microorganisms (carbohydrates). Hydrolytic enzyme activity confirms the high level of biological activity of soils of the MPs of the first and the second stages of degradation.

\section{Conclusions}

The current state of pasture soils (mountain meadowsteppe and mountain-meadow subalpine) and the degree of change of their properties at various levels of the pasture degradation were estimated. The obtained data suggest that the gradation of the pasture degradation stages for grasslands dominated by Bromus variegatus M. Bieb. can be used in soil conditions monitoring of the studied territories.

The analysis of the obtained data shows that the average values of the estimated soil indicators generally decrease with an increase of the pasture degradation stage. These changes are only tendency when comparing the meadows of the first and second degradation stages (DS1 and DS2). Soil, being a stable system, is subjected to less pronounced changes than vegetation cover at this level of the grazing load. Statistically significant differences were not detected by any soil indicator between MPs of DS1 and DS2. The greatest differences $(t=1.7-1.9 ; p=0.1)$ were found for the acidity of the soil suspension, the soil density, the humus content and the activity of phosphatase. Most of the listed indicators are stable and determined by soil genesis. This suggests that even at the initial degradation stages, negative processes occur, the development of which leads to the degradation of pasture soils.

When comparing the indicators for MPs of the second and third degradation stages (DS2 and DS3), the most alarming fact is a sharp decline $(\mathrm{t}=4.8-10.1 ; \mathrm{p}$ $<0.003$ ) of the soil layer thickness and the root mat horizon in areas that can be called severely degraded pastures (DS3). In addition, a significant change in the soil suspension acidity is revealed $(\mathrm{t}=2.7 ; \mathrm{p}=0.04)$ towards neutral values, as well as a significant decrease $(\mathrm{t}>2.5 ; \mathrm{p}<0.04)$ of all microbial indicators (basal and substrate induced respiration, Cmic contents and stocks). There is a steady tendency in reduction of the humus content $(\mathrm{t}=1.6 ; \mathrm{p}=0.2)$, phosphatase and invertase activity $(\mathrm{t}=1.1-1.3 ; \mathrm{p}=0.2-0.3)$.

Comparison of the average values of all measured soil parameters of the MPs with most preserved meadow systems (DS1) and the most damaged ones (DS3) indicate that most of the parameters are significantly reduced (the soil profile and root mat horizon thickness, the acidity of the soil suspension, the soil density, the humus content, SIR rate, the Cmic content, the phosphatase activity $(\mathrm{t}>2.5 ; \mathrm{p}<0.04))$. The differences in the values of other parameters are close to statistical significance (BR rate, dehydrogenase, catalase, invertase activity $(\mathrm{t}<2.0 ; \mathrm{p}>0.09)$.

The presented data indicate that the developed in this study differentiation of pasture degradation stages based on the parameters of the state of the vegetation cover determined in field conditions is also effective in assessing the state of pasture soils. In the absence of areas unaffected by anthropogenic activity (DS0), soils of meadows of the first degradation stage (DS1) can serve as a conditional reference for determining the degree of change in pasture soils during subsequent stages of degradation. In the soils of meadows of the second degradation stage (DS2), negative processes acquire the character of a stable trend. Further degradation of meadow vegetation cover also leads to significant degradation of pasture soils, and the negative processes in them are sharply intensified and clearly manifested. Soil degradation of meadows in the third degradation stage (DS3) is proved by the obtained statistical data. However, despite the negative changes, even severely degraded soils of mountain meadows have not lost their natural potential and are potentially capable of self-restoration with a decrease in pasture load.

The obtained information about the current state of pasture soils is necessary for control, monitoring, forecasting the state and preservation of mountain meadow ecosystems of the Central Caucasus, an unique economic and natural resource.

\section{References}

1. R.G. Gracheva, E.A. Belonovskaya, Izv. Ross. Akad. Nauk, Ser. Geogr., E. 1, 90-102 (2010)

2. E.G. Kolomyts, In the mountains of the Central Caucasus (Kabardino-Balkarian Book Publishing House, 1967)

3. Federal Law of the Russian Federation "Land Code of the Russian Federation" (dated October 25, 2001)

4. K.G. Magomedov, N. B. Berbekova, Successes of modern natural science. E. 8, 104-109 (2016)

5. E.N. Molchanov, Mountainous meadow-steppe soils in high mountains of the Eastern Caucasus region (2009)

6. Climate data of cities around the world // https://ru.climate-data.org (Electr. resource. Date of treatment: 03.30.2020)

प. E. Molchanov, Comparative characteristics of the main types of soils in the highlands of the North 
Caucasus (on the example of the KabardinoBalkarian and Dagestan ASSR) (Abstract of thesis. Dissertation. for competition sch. step. Cand. geogr. sciences. M., 1973)

7. Soils of the Kabardino-Balkarian Autonomous Soviet Socialist Republic and recommendations for their use (State Design Institute for Land Management SevKavNIIgiprozem, 1984)

๑. B.Kh. Fiapshev, High-mountain soils of the central part of the North Caucasus (KBSACA Publ.; 1996.)

प. V.V. Egorov, V.M. Fridland, E.N. Ivanova, Classification and diagnostics of soils of the USSR (Kolos, 1977)

10.World Reference Base for Soil Resources. International soil classification system for naming soils and creating legends for soil maps. World Soil Resources Reports E. 106, 181 (2014)

11. A.N. Filipchuk, Handbook of the forester (Publishing house of VNIILM. 2003)

11. V.N. Sukachev, S.V. Zonn, Methodical instructions for the study of forest types (Publishing House of the Academy of Sciences of the USSR, 1961)

11. V.S. Ipatov, Description of the phytocenosis ( $\mathrm{SPb}$.: Science. 1998)

10.V.V. Neronov, Field practice in geobotany in Central European Russia: Methodical manual (Publishing House of the Center for Wildlife Conservation, 2002)

10. S.M. Bebiya, Fir forests of the Caucasus (MGUL. Publ., 2002)

10. B.M. Mirkin, Results of Science and Technology of VINITI. Ser. Botany. E. 9, 123-140 (1989)

11. A.I. Galushko, Publishing house Rostov: the RGU. E. 1, 317 (1978)

10. N.L. Tsepkova, L.M. Goldberg, Transactions of the high-mountain geophysical institute. E. 71, 111-121 (1988)

प.. N.L. Tsepkova, News of the Samara Scientific Center of the Russian Academy of Sciences. E. 9, 919-925 (2007)

2․ E.N. Molchanov, Explanatory Text to the Soil Map of Kabardino-Balkar Republic (GUGK SM SSSR, 1990)

2".K.Sh. Kazeev, S.I. Kolesnikov, V.F. Val'kov, Soil Biological Diagnosis and Indication: Methodology and Methods of Research (Rostov. Gos. Univ., 2003)

2․ Soils. Laboratory methods for determination of physical characteristics (GOST 5180-2015)

2匹.F.Kh. Khaziev, Methods of Soil Enzymology (Nauka, 1976)

24. R.E. Creamer, R.P.O. Schultea, D. Stonea, A. Gal, P.H. Kroghc, G. Lo. Papa, P.J. Murraye, G. Pérès, B. Foerster, M. Rutgers, J.P. Sousai, A. Windingj, Ecological Indicators. E, 36, 409-418 (2014)

24. N.D. Ananyeva, Microbiological aspects of selfpurification and stability of soils (Nauka Publ.; 2003)
2—. Anderson T.H., Domsch K.H. Carbon links between microbial biomass and soil organic matter Eds: F. Megusar, M. Gantar (Perspectives in microbial ecology. Slovene Society for Microbiology. Ljubljana. 1986)

2․E.N. Molchanov, Pochvovedenie. E. 12, 1433-1448 (2010)

2匹. N.D. Ananyeva, E.V. Blagodatskaya, D.B. Orlinskiy, T. N. Myakshina, Pochvovedenie- Eurasian Soil Science, E. 11, $72-77$ (1993). ए

30. F.Kh. Khaziev, Bulletin of the Academy of sciences of the Republic of Bashkortostan. E. 2, 14-24 (2015) 